ISSN : 2337-5957 / e-ISSN : 2655-2833

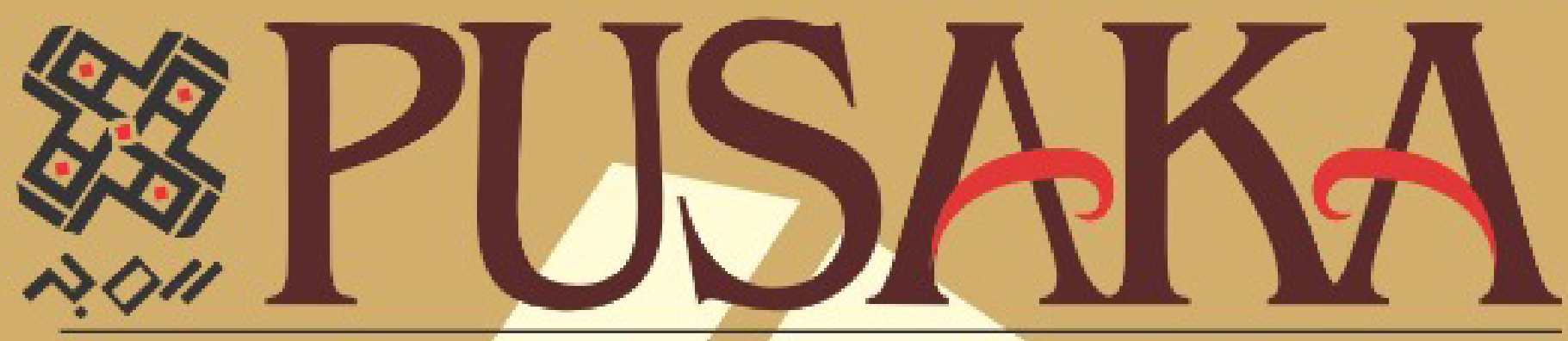

JURNAL KHAZANAH KEAGAMAAN

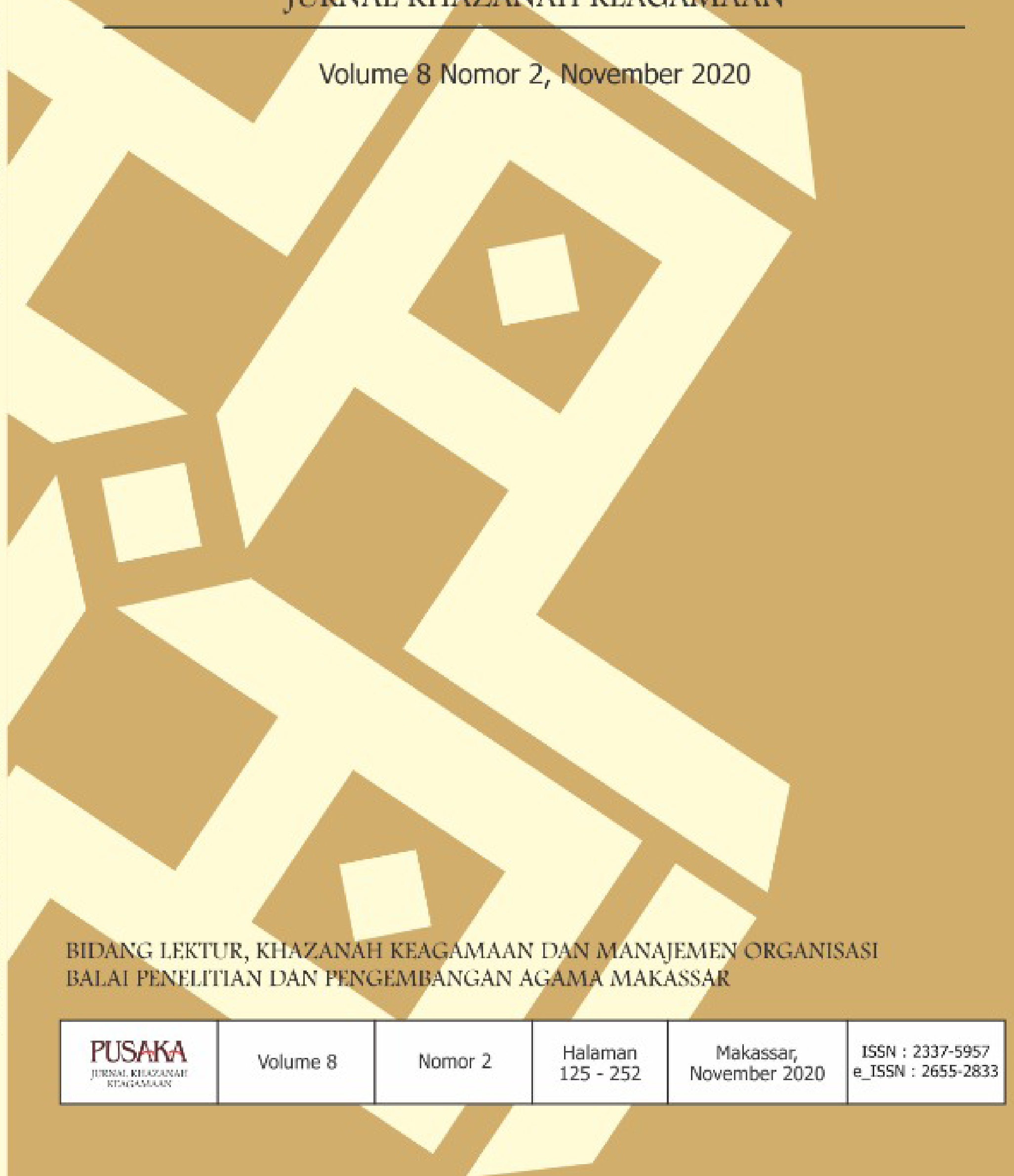


ISSN: 2337-5957 / E-ISSN: 2655-2833

\section{PUSAKA \\ Jurnal Khazanah Keagamaan \\ Vol. 8, No. 2, November 2020}




\section{PUSAKA \\ Jurnal Khazanah Keagamaan}

Vol. 8, No. 2, November 2020

PEMBINA

REDAKTUR AHLI

MITRA BESTARI

PEMIMPIN REDAKSI

DEWAN REDAKSI

KESEKRETARIATAN

Lay Out

ALAMAT REDAKSI
: H. Saprillah, M.Si.

: Dr. H. Abd. Kadir M., M.Ag. (Agama, Balitbang Agama Makassar)

: Prof. Dr. Muhammad Adlin Sila, Ph.D. (Kajian Agama dan Masyarakat, Badan Litbang dan Diklat Kemenag RI) Prof. Dr. H. Idham, M.Pd. (Kajian Agama dan Tradisi Keagamaan, Balai Litbang Agama Makassar)

Dr. H. Muhaemin (Kajian Pendidikan Agama dan Sosiologi Agama, Insititut Agama Islam Negeri Palopo)

Dr. Ulfiani Rahman (Kajian Pendidikan, dan Dirasah Islamiyah, Universitas Islam Negeri Alauddin Makassar).

Dr. Mustolehudin (Kajian Agama dan Tradisi Keagamaan, Balai Litbang Agama Semarang)

: Muh. Subair, SS., M.P.I.

: Abu Muslim, S.HI., M.HI.

Dra. Nelly

H. Muhammad Sadli Mustafa, S.Th.I., M.Pd.I.

Hamsiati, M.Hum.

Husnul Fahimah Ilyas, M.A.Hum

Muhammad Nur, MH.I.

Syarifuddin, S.S., M.Hum.

Wardiah Hamid, S.Ag, M.Hum

: Amru Ichwan Alwy, S.IPI.

Burhanuddin

Darwis, S.Pd.I.

Risma Yuliana Wahab, S.Kom

Syamsuddin, S.M.

: Nur Arisal, SE.

: Balai Penelitian dan Pengembangan Agama Makassar

Jl. A.P. Pettarani No. 72 Makassar 90222

Telp. 0411452952 Fax. 0411452982

Email: pusakajurnal@gmail.com 


\section{PUSAKA \\ Jurnal Khazanah Keagamaan \\ Vol. 8, No. 2, November 2020}

\section{DAFTAR ISI}

Tradisi Siklus Hidup Masyarakat Perkotaan di Era Normal Baru

(Studi Living Qur'an pada Masyarakat Pedalangan, Banyumanik, Semarang)

Mita Melina, Ulfi Putra Sany, dan Mustolehudin

Mengilhami Kreativitas Keberagamaan Masyarakat Melalui Perjumpaan

Islam dan Patuntung di Tanah Toa Kajang

Sylviah dan Abu Muslim

Makna dan Simbol Pada Tradisi Pembacaan Ratek Mauduk

di Komunitas Makassar

Husnul Fahimah Ilyas

Korelasi Fungsional Kalender Islam dan Pembayaran Zakat

Muh. Rasywan Syarif dan Naif

Islamisasi di Ajatappareng Abad XVI-XVII

Ahmad Yani

Merajut Moderasi Beragama dari Tradisi Pesantren

Abd. Kadir M

Jaringan Intelektual Ulama Pinrang

Syarifuddin

Kearifan Lokal Sintuwu Maroso sebagai Simbol Moderasi Beragama 


\section{PENGANTAR REDAKSI}

Pandemi COVID-19 belum berlalu, di tengah penerapan tatanan kehidupan baru yang berbasis pada adaptasi perilaku hidup bersih dan sehat, kini hadir lagi edisi Pusaka Jurnal Volume 8 Nomor 2, November 2020. Sebuah upaya konsisten untuk terus menghadirkan jurnal ilmiah yang berbasis hasil penelitian dalam bidang, lektur dan khazanah keagamaan. Tidak mudah untuk menjaga ritme ketepatan penerbitan dan kualitas artikel yang memenuhi kualifikasi terbaik. Tetapi, artikelartikel pada edisi ini tampak berkembang lebih baik, ditandai dengan semakin minimnya yang melewati ambang batas plagiasi dari artikel-artikel yang diterima. Hal ini menunjukkan kesadaran para penulis akan pentingnya menjaga integritas dan akuntabilitas pribadi sebagai bagian dari masyarakat ilmiah yang bertanggung jawab.

Persebaran wilayah penulis dan wilayah kajian selanjutnya akan menjadi perhatian dalam penentuan artikel yang akan diterima. Hal ini dapat ditunjang oleh penyebarluasan informasi jurnal online dan diikuti oleh peningkatan sitasi jurnal yang menjadi keharusan untuk selalu ditingkatkan. Iklim penulisan artikel yang menjaga integritas penulis dari plagiarisme sekali lagi akan sangat membantu untuk menjaga keberlangsungan kualitas artikel, penyebarluasan artikel, dan ketertarikan para penulis dari berbagai daerah untuk mempercayakan artikelnya menjadi bagian dari terbitan Pusaka Jurnal Khazanah Keagamaan pada edisi-edisi yang akan datang.

Edisi kali diharapkan dapat menghadirkan berbagai artikel yang informatif dan solutif terhadap permasalahan sosial keagamaan dan tuntutan perkembangan zaman. Karena itu, artikel terkait kearifan lokal menjadi warna yang dominan, khususnya yang membincang tentang pengembangan sikap moderasi beragama. Basis artikel sebagai deskripsi empiris dari keadaan masyarakat yang menjadi sasaran penelitian, memperlihatkan wajah dan watak keberagamaan dalam keberagaman yang dinamis. Suku-suku bangsa yang beragama dapat dimaknai sedang berupaya mengangkat citra diri kesukuannya dengan memberi manfaat yang sebesar-besarnya bagi terciptanya kualitas kebangsaan yang lebih baik.

Makassar, 01 November 2020

Pemimpin Redaksi,

Muh. Subair 


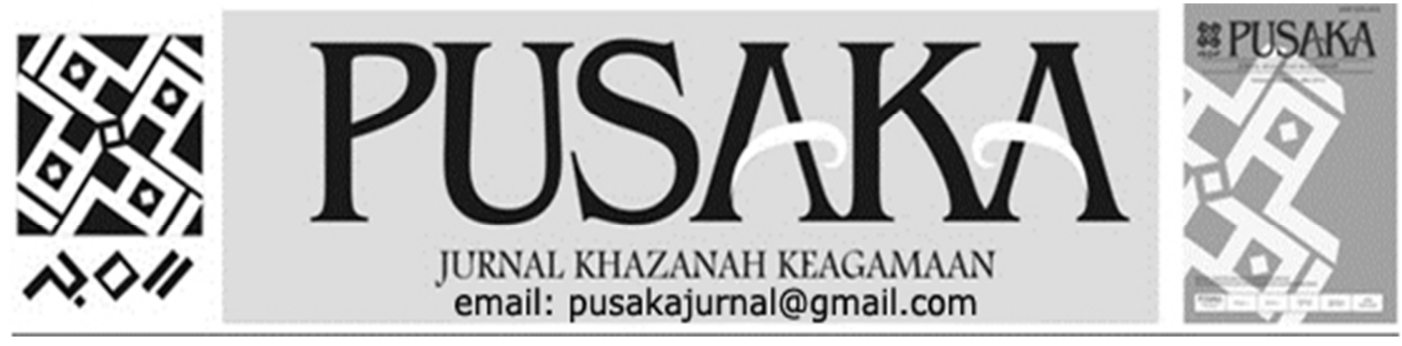

\title{
Jaringan Intelektual Ulama Pinrang
}

\section{The Intellectual Network of Ulama In Pinrang}

\author{
Syarifuddin \\ Balai Penelitian dan Pengembangan Agama Makassar \\ Jl.A.P.Pettarani No.72 Makassar. Telp:0411-452952 \\ Email: syarifuddinamir84@yahoo.com
}

\begin{tabular}{|c|c|}
\hline $\begin{array}{c}\text { Info } \\
\text { Artikel }\end{array}$ & Abstract \\
\hline $\begin{array}{c}\text { Diterima } \\
24 \\
\text { Juni } \\
2020 \\
\text { Revisi I } \\
27 \\
\text { Agustus } \\
2020\end{array}$ & $\begin{array}{l}\text { Tulisan ini menggambarkan pola jaringan intelektual Pinrang. Studi menggunakan } \\
\text { pendekatan ilmu sejarah sebagai sudut pandang dengan mengumpulkan sumber } \\
\text { sejarah yang terkait. Oleh karena secara historis, studi ini dibatasi pada fase Abad } \\
\text { XX. Beberapa ulama yang menjadi fokus kajian antara lain. Habib Hasan bin Alwi } \\
\text { bin Sahl di Lero Pinrang, KH. Muhsen Umar, KH. Abd. Shamad, KH. Abd. } \\
\text { Rahman Ambo Dalle. Pola pembentukan jaringan tersebut berupa jaringan } \\
\text { intelektual yang belajar ke Mekah seperti Habib Hasan bin Alwi bin Sahl dan KH. } \\
\text { Abd. Rahman Ambo Dalle. Secara khusus, KH. Abd. Rahman Ambo Dalle terlebih } \\
\text { dahulu belajar ke Madrasah Arabiyyah al-Islamiyyah Sengkang di Wajo sebelum } \\
\text { pergi ke Mekah. Pola pembentukan jaringan lainnya yakni berupa jaringan } \\
\text { intelektual secara lokal yakni mereka belajar pada lembaga pendidikan yang } \\
\text { berkembang pada masanya seperti pengajian tradisional di Salemo. Disamping itu, } \\
\text { disebutkan diantara ulama tersebut juga belajar di Arabiyyah al-Islamiyyah } \\
\text { Sengkang di Wajo di bawah asuhan KH. Muh. Asad. Selanjutnya, mereka pun } \\
\text { kemudian mengembangan jaringan intelektual dengan melaksanakan pengajian } \\
\text { kitab secara tradisional, mengajarkan tarekat serta mendirikan lembaga pesantren. } \\
\text { Kata Kunci: jaringan intelektual, Darud Dakwah Wal Irsyad, ulama, pengajian } \\
\text { tradisional. }\end{array}$ \\
\hline $\begin{array}{c}\text { Revisi II } \\
7 \\
\text { Oktober } \\
2020 \\
\\
\text { Disetujui } \\
20 \\
\text { Oktober } \\
2020\end{array}$ & $\begin{array}{l}\text { This paper describes the pattern of the Pinrang intellectual network. The study } \\
\text { uses a historical science approach as a point of view by collecting related } \\
\text { historical sources. Therefore, historically, this study is limited to the phase of the } \\
\text { XX century. Several scholars who became the focus of the study, among others. } \\
\text { Habib Hasan bin Alwi bin Sahl in Lero Pinrang, KH. Muhsen Umar, KH. Abd. } \\
\text { Shamad, KH. Abd. Rahman Ambo Dalle. The network formation pattern is in the } \\
\text { form of intellectual networks who study in Mecca, such as Habib Hasan bin Alwi } \\
\text { bin Sahl and KH. Abd. Rahman Ambo Dalle. In particular, KH. Abd. Rahman } \\
\text { Ambo Dalle first studied at Madrasah Arabiyyah al-Islamiyyah Sengkang in Wajo } \\
\text { before going to Mecca. Another network formation pattern is in the form of a local } \\
\text { intellectual network, where they learn at educational institutions that developed at } \\
\text { that time, such as traditional recitation in Salemo. Apart from that, it was stated } \\
\text { that among these scholars also studied at Arabiyyah al-Islamiyyah Sengkang in } \\
\text { Wajo under KH. Muh. Asad. Furthermore, they then developed intellectual } \\
\text { networks by carrying out traditional book recitations, teaching tarekat and } \\
\text { establishing pesantren institutions. } \\
\text { Keywords: intellectual network, Darud Dakwah Wal-Irsyad, ulama }\end{array}$ \\
\hline
\end{tabular}




\section{PENDAHULUAN}

Perkembangan ajaran Islam di suatu daerah tak bisa dilepaskan dari peran dan dakwah ulama sebagai aktor pewaris risalah agama yang dibawa oleh Rasulullah Saw. Tak terkecuali di daerah Pinrang. Sejak masuknya Islam di daerah Sulawesi Selatan yang secara resmi diproklamirkan oleh Raja Gowa Sultan Alauddin pada tahun 1605 (Sewang, 2005, p. 2) berkat dakwah dari seorang ulama yakni Datuk Ri Bandang. Agama Islam kemudian menyebar ke wilayah sekitar termasuk halnya daerah Pinrang. Menurut salah satu persi bahwa, kehadiran agama Islam di wilayah Pinrang di yakini ketika wilayah kerajaan Sawitto mendapat anjuran dari Raja Gowa pada tahun 1607. Dasarnya penerimaannya yaitu adanya kesepakatan antar kerajaan tersebut bahwa apabila salah satu diantara menemukan jalan kebaikan maka harus disampaikan kepada yang lainnya (Kila, 1998, p. 106). Dalam kurun beberapa waktu, agama Islam kemudian menjadi agama mayoritas. Seperti disebutkan sebelumnya bahwa realitas ini tak bisa dipisahkan dari peran para ulama.

Proses transformasi ajaran Islam di masyarakat sudah berlangsung beberapa abad lamanya. Problem yang terjadi kemudian adalah masa kini tak mampu melacak peran-peran ulama tersebut. Salah satu faktornya adalah minimnya kajian terkait sejarah ulama. Penulisan sejarah yang dilakukan oleh para sejarahwan lebih berbasis pada sejarah politik yang menceritakan perkembangan serta intrik pada suatu kekuasaan. Produk sejarah ini juga banyak diadopsi pada buka ajar sejarah di sekolah. Pada akhirnya, sejarah yang menceritakan perjuangan ahli agama dalam mendakwahnya ajaran Islam sangat minim didapatkan. Contoh kecil misalnya, pelajaran di sekolah hampir tidak mengungkap peran Sykeh Yusuf Al-Makassary dalam menyebarkan ajaran agama. Ia hanya dikenal sebagai tokoh perlawanan di daerah Banten yang kemudian diasingkan ke Afrika Selatan. Perannya pun dianggap masih kalah dibanding figur Sultan Agung sebagai Raja Banten.

Oleh karena itu tulisan ini mencoba merefleksi kembali jejak perjuangan para ulama berbasis jaringan intelektualnya. Hal penting, karena seorang ulama tidak lahir sebagai ulama begitu saja. Ada aktor ulama lainnya yang membentuk seorang ulama hingga akhirnya ia juga meraih taraf ulama. Adalah sebuah warisan ilmu pengetahuan yang diwariskan dari generasi ke generasi. Tak kalah pentingnya adalah warisan budi pekerti berupa akhlakul karimah. Artinya seorang ulama tidak akan cukup disebut ulama jika hanya sekedar memiliki ilmu agama. Tetapi lebih dari itu, ia juga harus memiliki akhlak yang mulia untuk dijadikan panutan umat.

Secara sederhana, para ulama dahulu mentransformasikan ilmu kepada muridnya melalui lembaga pengajian baik itu secara talaqqi maupun halaqah. Dalam perkembangan selanjutnya, beberapa ulama kemudian mendirikan lembaga pendidikan agama formal seperti $\mathrm{KH}$. Muh. Asad di Wajo yang mendirikan Madrasah Arabiyah al-Islamiyah Sengkang pada tahun 1930 (Pawiloy. et.al, 1981, p. 81). Lembaga ini kemudian berubah menjadi Pesantren Asadiyah sebagai bentuk penghormatan kepadanya. Dari Madrasah inilah muncul banyak ulama yang diasuh langsung KH. Muh. As'ad. 
Mereka inilah kemudian mengembangkan proses intelektual sang guru dengan ditandai berdirinya beberapa pesantren di beberapa daerah di Sulawesi Selatan. Proses pewarisan seperti inilah yang disebut sebagai jaringan intelektual ulama.

Di samping itu pola tersebut di atas, banyak juga ulama termasuk halnya di Sulawesi Selatan yang memilih untuk belajar langsung ke Mekah dan Madinah. (Azra, 2007) menyebutkan bahwa kota Mekah memiliki posisi yang sangat penting bagi umat Islam yakni ia adalah kiblat umat Islam sekaligus tempat awal berkembangnya ajaran Islam. Pada saat yang sama, banyak ulama menjalankan pengajian di Mekah. Salah satu faktor memicu pembentukan jaringan ini, yaitu prosesi pelaksanaan ibadah yang rutin dilaksanakan setiap tahunnya. Oleh karena itu, banyak ulama yang memilih naik haji ke Mekah sekaligus memanfaatkan waktu untuk menimba ilmu kepada ulama di kota tersebut.

Ulama pertama yang dikenal membentuk jaringan Sulawesi-Mekah adalah Syekh Yusuf Al-Makassari. Dalam perjalanannya belajar ke Mekah, ia singgah di beberapa daerah seperti Banten, Aceh dan Yaman (Lubis, 1996). Gambaran perjalanan ini secara langsung membentuk ulama Nusantara-Timur Tengah. Azra dalam bukunya memaparkan secara khusus figur Syekh beserta perjalanan hidupnya mengembara mencari ilmu serta berjuang menyebarkan dakwah Islam (Azra, 2007). Dalam perkembangannya, banyak ulama Sulawesi yang kemudian belajar ke Mekah seperti Syekh Abd. Rasyid Bugis dan putranya KH. Muh. As'ad dari Sengkang Wajo. tradisi belajar ke Mekah ini juga dilakukan oleh beberapa calon Qadhi Kerajaan Bone, diantaranya: Syekh Ahmad, KH. Adam, KH. Safiyanah, KH. Muhammad Yusuf, KH. Abd. Wahid, KH. Sulaiman, KH. Muh. Rafi dan KH. Junaid (Ridhwan, 2016). Selanjutnya terdadapat ulama-ulama yang belajar di Nusantara, atau belajar dari ulama alumni Mekkah, seperti AGH. Huzaifah dan AGH Muhammad Abduh Pabbajah (Muh Subair, 2011; Muhammad Subair, 2018).

Berdasarkan latar belakang yang telah dikemukakan di atas, maka masalah penelitian ini, yaitu: Bagaimana Jaringan Ulama di Pinrang? Pertanyaan ini dijabarkan dalam sub permasalahan sebagai berikut: Bagaimana proses pembentukan jaringan inteluktual ulama di Pinrang? Penelitian ini bertujuan menjawab permasalahan di atas yaitu: Untuk mengetahui proses pembentukan jaringan intelektual ulama di Pinrang serta dampak dari pembentukan jaringan intelektual ulama Sulawesi Selatan di Pinrang.

Kajian yang sangat penting terkait dengan tulisan ini yaitu artikel yang ditulis oleh (Hamid, 2019, pp. 405-419) yang memaparkan kiprah ulama Pinrang . ia menyebutkan bahwa beberapa ulama memiliki kiprah dalam pengembangan dakwah Islam di Pinrang KH. Abd. Latif, KH. Zaenal Abidin, KH. Hafid Karim serta KH. Abd. Hamid. Diantara kiprah tersebut yaitu adanya pengajian halaqah yang dihadiri oleh masyarakat. Disamping itu, mereka juga di Kementerian Agama Kabupaten Pinrang seperti KH. Zaenal Abidin dan KH. Hafid Karim. Kiprah lainnya yang dilakoni ulama Pinrang menjadi Qadi di Kerajaan Sawitto. Jabatan ini dijabat oleh KH. Abd. Hamid. Terkait dengan jaringan 
ulama tersebut, disebutkan bahwa mereka terkoneksi dengan jaringan lembaga pendidikan yang berkembang sebelumnya sebagai tempat mereka belajar yakni pengajian tradisional di Salemo dan Campalagian serta MAI di Sengkang Wajo yang diasuh oleh KH. Muh. Asad. Disamping itu, mereka juga terkoneksi dengan jaringan ulama Mekah.

Artikel lain yang ditulis oleh dengan tema yang sama tetapi dengan lokus yang berbeda yakni memaparkan kiprah Ulama Parepare dan Sidrap. Ia menyebutkan nama KH. Mahmud Fasieh, KH. Muhammad Sanusi Maggu, KH. Jamal Usman Padaelo, KH. Bahsen Salman, dan KH. Lukman Hakim. Kiprah mereka mereka mirip dengan pola kiprah ulama Pinrang di artikel sebelemnya yakni mereka berkiprah dalam memberikan Pendidikan langsung kepada masyarakat serta mengabdi di lingkungan pemerintahan dengan menjadi pimpinan di lembaga Mahkamah Syariah. Disamping itu, sebagian ulama tersebut merupakan kader atau murid dari $\mathrm{KH}$. Abdurrahman Ambo Dallo ketika ia mengembangkan organisasi Darud Dakwah Wal Irsyad di Parepare (Hamid, 2018).

Studi terkait jaringan ulama di Sulawesi Selatan secara spesifik diutarakan oleh Syamsuddin Arif yang berjudul Jaringan Pesantren di Sulawesi Selatan (1928-2005). Buku ini merupakan hasil disertasinya di UIN Syarif Hidayatullah Jakarta. Dalam kajiannya, menyebutkan bahwa Muh. As'ad (Gurutta Sade) merupakan aktor jaringan pembentukan ulama pesantren di Sulawesi Selatan dengan merujuk pada beberapa muridnya yang mendirikan pesantren yang masih eksis hingga kini. Diantaranya, Abdurrahman Ambo Dalle (Pesantren DDI Mangkoso, Pesantren DDI Parepare dan Pesantren Manahil Ulum Kaballangan Pinrang), Daud Ismail (Pesantren Yastrib Soppeng), Muh. Abduh Pabbajah (Pesantren Al-Furqan Pare-pare), Abd. Muin Yusuf (Pesantren al Urwatul Wustqa Rappang Sidrap), Lanre Said (Pesantren Darul Huffazh Tuju-tuju Kajuara Bone), Ahmad Marzuki Hasan (Pesantren Darul Istiqamah Maros), Abdul Kadir Khali (MDIA Bontoala Makassar), Fasih Mustafa (DDI Takkalasi Barru), dan lain sebagainya (Arif, 2008, p. 95). Walaupun kajian membahas jaringan ulama secara luas di Sulawesi Selatan, namun kajian dibatasi pada ulamaulama yang merupakan murid atau alumni dari MAI Sengkang yang dibina oleh Gurutta Muh. As'ad.

Teori yang sangat relevan dengan tulisan ini yaitu teori jaringan. Ritzer memaparkan teori ini bahwa yaitu fokus utamanya yaitu adanya hubungan-hubungan sosial atau pola objektif ikatan-ikatan yang menghubungkan para anggota (Ritzer, 2014, p. 747). Jika dibawa kepada pola jaringan ulama yaitu didefensisikan sebagai pola hubungan ulama secara sosial baik itu dengan guru atau muridnya ataupun hubungan dengan masyarakat. Hanya saja, hubungan dalam kajian ini difokuskan pada koneksi intelektua antara ulama dengan guru dan muridnya.

\section{METODE}

Penelitian ini adalah penelitian kualitatif yang memotret jaringan intelektual ulama di Pinrang. Pendekatan yang digunakan yaitu pendekatan historis dengan memaparkan perkembangan jaringan 
intelektual ulama dari perspektif kesejarahan. Penelitian ini dilaksanakan di Kabupaten Pinrang dengan membatasi pada Periode Abad XX. (Gottschalk, 2006, p. 174) menyebutkan penyusunan kronologi yang berdasarkan periode tertentu menjadi menjadi norma yang harus diperhitungkan oleh peneliti sejarah. Oleh karena itu, ini pembatasan periode pada kajian ini menjadi sangat penting. Secara umum, pengumpulan data dalam penelitian ini yaitu mengacu pada pengumpulan data penelitan kualitatif yakni : observasi terhadap lingkungan sosial kehidupan ulama, wawancara dengan informan yang memiliki informasi seputar ulama seperti keluarga, murid, tokoh agama atau masyarakat, serta studi kepustakaan yang relevan dengan kajian ini. Sebagaimana halnya penelitian kualitatif, peneliti kemudian mengolah data tersebut mulai dari pengumpulan data hingga analisis data (Sugiyono, 2010) Selanjutnya, analisis data dilakukan dengan analisis kualitatif deskriptif.

\section{HASIL DAN PEMBAHASAN Jaringan Tradisional Halaqah}

Defenisi jaringan tradisional pada tulisan yaitu jaringan ulama yang melaksanakan proses pewarisan intelektual keislaman berupa pengajian kitab kuning dalam bentuk tradisional seperti sorogan dan halaqah. Bentuk ini biasanya dipraktekan juga di pesantrenpesantren yang mengajarkan tradisi kitab kuning (Dhofier, 2011). Sistem ini dipilih karena dianggap sebagai media yang sangat ampuh dalam pendalaman ajaran agama secara mendalam. Sistem ini biasanya dikelola seadanya tanpa mengacu pada manajemen pendidikan modern seperti sekolah atau madrasah. Proses pewarisan keilmuwan dilakukan oleh seorang ulama dengan mengajarkan kitab-kitab tertentu kepada muridnya. Tempat pelaksanaanya yaitu masjid atau rumah ulama itu sendiri.

Dalam beberapa penelusuran di Pinrang, sistem pembelajaran ini dilakukan oleh beberapa ulama, diantaranya yang paling terkenal yaitu KH. Abd. Shamad, seorang ulama yang lahir di Langnga Pinrang. Tahun kelahirannya tidak diketahaui secara pasti. Menurut beberapa informan, ia segenerasi dengan Ambo Dalle (lahir tahun 1900). Awalnya sekitar tahun 1930, ia ke Salemo memperdalam ilmu agama (mangngaji kitta) selama 4 tahun. Menurut informasi lisan di Salemo, ia secara khusus belajar kepada KH. Abd. Rasyid serta pada ulama lainnya. Rihlah ilmiahnya kemudian dilanjutkan ke Tanah Suci mekah belajar di Darul Ulum selama 4 tahun. Tidak diperoleh informasi secara pasti siapa gurunya di Mekah, namun di periode yang hampir sama ada beberapa ulama Sulawesi Selatan yang pergi Ke Mekah belajar Darul Ulum seperti Abdurrhaman Ambo Dalle, Abdul Malik Muhammad, dan Muhammad Nur. Dengan tempat belajar yang sama, diduga bahwa mereka berguru kepada ulama yang sama.

Setelah belajar di Tanah Suci, KH. Abd. Shamad kemudian pulang ke Pinrang dan tinggal menetap di Paleteang (sekarang depan terminal Pinrang). Ia membawakan pengajian di masjid lama Pinrang (Masjid Raya), dengan dibantu oleh seorang asisten sekaligus murid setia bernama Said Mantaka (Lahir 5 Juli 1931. Kitab yang dikaji yaitu Kifayatul Akhyar dan 
Kasyifah al Saja. Kitab ini merupakan kitab fikih yang berorientasi pada Mazhab Syafi'iyyah.

Disamping mengajar di masjid, ia mengajar di rumahnya. Muridnya antara lain KH. Zaenal Abidin (Mantan Kandepag Pinrang dan Ketua MUI), KH. Abd. Hafid Karim (Qadhi Sawitto/Pengurus DDI Hasil Muktamar I 1948). Tradisi belajar mengajar dengan sistem tradisional dilakoni $\mathrm{KH}$. Abd. Shamad hingga ia wafat dan dimakamkan di pekuburan Pacongan Kota Pinrang. Makamnya hanya berupa batu nisan yang kini tidak bisa lagi dikenali. Akibatnya informasi tentang waktu meninggalnya tidak diketahui secara pasti. Namun, berdasarkan informasi dari murid dekatnya yaitu Said Mantakka, bahwa KH Abd. Shamad diperkirakan wafat pada tahun 1970-an. Informasi didasarkan pada proses pengajian kitab kuning di Masjid Raya digantikan oleh Said Mantakka (Wawancara dengan Said Mantakka Murid KH. Abd. Shamad di Pinrang) tanggal 17 Maret 2017). Tradisi yang sama juga dilakoni oleh beberapa ulama seperti KH. Abd. Latif (sebelumnya belajar Kitab Kuning di Campalagian Polman) dan KH. Rabe Baddulu yang kesemuanya berasal dari Langnga daerah asal KH. Abd. Samad

Di daerah pesisir pantai, tradisi kajian kitab kuning dalam bentuk tradisional juga dilaksanakan oleh Habib Hasan Bin Alwi Jamalul Lail seorang ulama keturunan Arab yang menetap Ujung Lero Pinrang. Habib Hasan lahir di Pambusuang sekitar tahun 1894. Ayahnya seorang Ulama besar bernama Habib Alwi bin Abdullah Bin Sahl Jamalullail, pernah mengabdi di Pambusuang dan Campalagian dan dikenal dengan sebutan Puang Towa. Pada usia kanak- kanak, Habib Hasan dikirim oleh ayahnya menuntut ilmu ke tanah Suci Mekah kepada beberapa ulama kurang lebih 30 tahun lamanya (Sahl, 2014, pp. 64-65). Berdasarkan wawancara, diantara gurunya di Mekah yaitu Syekh Said al Yamani Mufti Syafi'iyyah, disamping itu, ia juga bersahabat dengan Syekh Hasan al-Yamani putra dari gurunya.

Setelah sekian lama menuntut ilmu di tanah Suci, ia kemudian pulang ke Mandar tepat ke tanah kelahirannya Pambusuang menyebarakan dakwah Islam sekaligus mengadakan pengajian kitab. Diantara murid-muridnya di Pambusuang yaitu: KH. Abd. Hafidz, KH. Abdul Rasyid (Imam Sabang Subik), KH. Syuaib (Imam Syuhada Polewali), KH. Muh Suyuti (Imam Napo), KH. Abdullah (Imam Masjid Taqwa Pambusuang), S. Thaha al Mahdaly. S. Husen Alwy Alatas.

Pada saat meletusnya peristiwa pemberontakan DI/TII yang dipimpin oleh Kahar Muzakkar, daerah Mandar juga termasuk daerah yang bergolak hingga akhirnya Habib Hasan juga tak luput dari incaran pasukan Kahar. Atas Saran dari S. Mengga, ia kemudian mengungsi ke Ujung Lero melewati jalur laut demi alasan keamanan. Disinilah ia kemudian melanjutkan dakwah Islam dan tradisi pengajian kitab hingga akhirnya hayatnya sehingga ia lebih dikenal dengan sebutan Puang Lero. Disamping itu juga ia memprakarsai pembangunan Masjid Jami al Muhajirin Ujung Lero. Diantaranya muridnya yang terkenal di Lero yaitu KH. Muchtar Husein mantan Ketua MUI Sulawesi Selatan. Habib Hasan menghembuskan nafas terakhir pada 8 Oktober 1973 dan dimakamkan di samping kiri Masjid 
Jami Al Muhajirin Ujung Lero Pinrang (Sahl, 2014).

\section{Jaringan Darud Dakwah wa Irsyad}

Organisasi Darud Da'wah wal Irsyad adalah organisasi sosial keagamaan yang didirikan oleh ulamaulama Sulawesi Selatan. Inisatif pendiriannya bermula dari Musyawarah Alim Ulama di Soppeng 17 Pebruari 1947. Pelaksanaan musyawarah ini merupakan usul dari pertemuan awal antara KH. Daud Ismail, KH. Abdrrahman Ambo Dalle, Syekh Abdurrahman Firdaus dan KH. Muhammad Abduh Pabbajah (Kabry, 2006, p. 7) Musyawarah ini dihadiri oleh berbagai ulama dari beberapa daerah seperti Syekh Abdurrahman Firdaus (Pare-pare), Muhammad Abduh Pabbajah (Allakuang Sidrap), Muh. Tahir (Qadi Balanipa Sinjai), Zainuddin (Majene), M. Kittab (Qadi Soppeng Riaja Barru), Abd. Muin Yusuf (Qadi Sidenreng Sidrap), dan lain sebagainya. Kehadiran beberapa ulama dalam musyawarah ini menandakan adanya hubungan yang erat antara ulama-ulama di berbagai daerah di Sulawesi Selatan (termasuk Sulawesi Barat sekarang ini). Situasi konteks di saat itu, Negara Kesatuan Republik Indonesia yang baru saja memproklamirkan kemerdekaannya pada tanggal 17 Agustus 1947. Namun, rakyat harus kembali berjuang mempertahankannya karena Belanda kembali ingin menanamkan pengaruhnya di Nusantara termasuk di Sulawesi. Usaha Belanda ini kemudian direspon oleh rakyat dengan perlawanan dimana-mana, hingga akhirnya terjadilah peristiwa korban 40.000 jiwa di seluruh wilayah Sulawesi Selatan pada tahun 1947. Peritiwa ini merupakan pembantaian dilakukan oleh Belanda di bawah komando Westerling yang dikenal dengan "Peristiwa Pembantaian Korban 40.000 Jiwa". Korban jiwa dalam peristiwa berasal dari berbagai daerah yaitu, Mandar, Pinrang, Sidrap dan Pare-pare. Dalam peristiwa ini, beberapa ulama tak luput dari korban kebengisan pasukan Westerling seperti KH. Ma'ruf dan Abdul Waris beserta guru yang ditugaskan oleh Abdurrahman Ambo Dalle di MAI Baruga Majene (Sudirman, 2008, p. 66). Dilatari situasi sulit tersebut, pertemuan alim ulama ini lahir sebagai respon masa depan pendidikan agama umat agar tetap dapat berjalan. Oleh karena itulah, muncul usulan untuk membentuk sebuah jaringan organisasi ulama yang menjamin kontiniutas pendidikan agama tetap bisa berjalan. Setelah mempertimbangkan berbagai usulan, disepakatilah bahwa nama organisasi tersebut adalah Darud Da'wah wal Irsyad disingkat DDI. Nama Darud Da'wah wal Irsyad merupakan usulan dari Syekh Abdurrahman Firdaus yang sekaligus menjadi penasehat bersama Syekh Ali Mathar dari Rappang. Pada awalnya, organisasi ini merupakan perkumpulan para ulama, namun akhirnya bertransformasi sebagai Organisasi Sosial Keagamaan yang merangkul berbagai pihak sebagai respon perkembangan zaman. Walaupun demikian, misi utama dari organisasi ini masih tetap sama yaitu mengembangkan pendidikan agama guna mencetak ulama.

Berbicara ulama DDI tentu tak bisa dilepaskan dari sosok $\mathrm{KH}$. Abdurrahman Ambo Dalle sebagai salah satu ulama pencetus lahirnya DDI sekalgus figur yang paling lama memimpin DDI. Ambo Dalle lahir 
tahun 1900 di Tanasitolo Wajo. Saat kecil ia belajar di Volk School kemudian dilanjutkan di sekolah guru (kweek school) Serikat Islam Makassar. Pada tahun 1931, ia kemudian melanjutkan pendidikan agama di MAI Sengkang di bawah asuhan KH. Muh. As'ad. selanjutnya ia ke Mekah menunaikan Ibadah Haji sekaligus belajar pada periode tahun 1934-1937. Selain KH. Muh. As'ad, ia tercatat pernah belajar pada $H$. Syamsuddin, Syekh Ambo Emme, Syekh Abdul Rasyid, Syekh Mahmud al Jawwad dan Syekh Hasan al Yamani (Ondeng, 2007, p. 7). Selanjutnya ia kembali MAI Sengkang belajar pada Gurutta Muh. As'ad sekaligus mengajar membantu gurunya dalam mengembangkan madrasah hingga datanglah sebuah permintaan dari Arung Soppeng Riaja Andi Muhammad Dagong bersama Qadi H. Kittab untuk berdakwah di Barru. Perimntaan itu tak bisa ditolak oleh Ambo Dalle hingga pada tahun 1938 berdirilah MAI Mangkoso di bawah kepemimpinan Ambo Dalle dibantu beberapa guru yang umumnya alumni MAI Sengkang, yaitu: KH. Burhanuddin, KH. Makki Barru, KH. Abd. Rasyid Ajakkang, KH. Abd. Kadir Balusu, KH. M. Qasim Pancana, KH. Amin Nashir, KH. Harun alRasyid, KH. Abd. Kadir Khalid, KH. Abd. Hannan, KH. Abd. Rahman Mattameng, KH. Muh. Aqib Siangka, Ustadz Haddad, KH. Amberi Said dan lain sebagainya (Anshory Ch, 2009, p. 59).

Pada 16 Februari 1947, ia mengikuti pertemuan dengan beberapa ulama di Soppeng. Hasil pertemuan tersebut yaitu iniasitif pendirian sebuah ormas yang menampung aspirasi keberlangsungan dakwah ulama yang kemudian dikenal dengan Daru Dakwah Wal Irsyad (DDI). Selanjutnya, ia kemudian melebarkan sayap ke Parepare dengan mendirikan Pesantren DDI Parepare di Ujung Lare, dibantu beberapa ulama seperti Syekh Abdurrahman Firdaus, KH. Muh. Abduh Pabbajah, KH. Abubakar Zaenal, KH. Yusuf Hamzah, KH. Aqib Siangka, dan lain sebagainya (Wawancara dengan KH. Lukmanul Hakim Pimpinan Pesantren DDI Manahil Ulum Kaballangan Pinrang sekaligus alumni Pesantren DDI Ujung Lare Parepare di Pinrang Maret 2017). Pada 1963, ia juga menggagas terbentuknya Madrasah Dirasah Ulya (haitul Takaful) yang Pesantren DDI, Pesantren Yastrib Soppeng, Pesantren Modern al-Hadist Biru Bone, dan Pesantren al Urwatul Wutsqa Sidrap.

Pada tahun 1977, Ambo Dalle memutuskan bergabung dengan Golkar. Pilihan masuk Golkar sendiri merupakan hasil istikharah dan pemikiran yang panjang terkait plus minus dan akibatnya terhadap organisasi DDI. Pertimbangan bahwa sikap refresif pemerintah Orde Baru terhadap tokoh Islam khususnya yang pernah terlibat dalam peristiwa DI/TII menjadi salah satu alasan. Walaupun demikian, pro dan kontra terhadap sikap Ambo Dalle tetap terjadi salah satunya yaitu banyak santri Pesantren DDI Ujunglare Parepare yang dipimpin langsung oleh beliau ramai-ramai meninggalkan asrama pesantren. Sementara yang tersisa hanya puluhan orang santri. Akibatnya, ia merasa kecewa dan memutuskan pindah ke Kaballangan Pinrang dan mendirikan Pesantren DDI Manahil Ulum Kaballangan. Di Kabballangan dibantu oleh, KH. Andi Syamsul Bahri Galigo, KH. Abd. Rahim Arsyad, KH. Yunus 
Shamad, KH. Lukmanul Hakim yang kesemuanya merupakan alumni Pesantren DDI Ujung Lare (Wawancara dengan KH. Lukmanul Hakim Pimpinan Pesantren DDI Manahil Ulum Kaballangan Pinrang sekaligus alumni Pesantren DDI Ujung Lare Parepare di Pinrang Maret 2017)

Keberadaan Gurutta Ambo

Dalle di Pinrang menjadi berkah tersendiri daerah itu, dimana pasca berdrinya Pesantren DDI Manahilul Ulum Kaballangan, diikuti kemudian Pesantren DDI lainnya seperti DDI al Taqwa Jampue, DDI Patobong dan DDI Lerang-lerang. Pada akhirnya Pinrang tercatat sebagai daerah yang memiliki pesantren DDI terbanyak dari daerah lainnya disamping keberadaan STAI DDI Pinrang. Pesantren tersebut merupakan hasil bentukan murid-murid Gurutta Ambo Dalle.

Disamping figur Ambo Dalle, tokoh DDI yang pernah menetap di Pinrang tepatnya di Jampue yaitu KH. Ali Yafie seorang guru besar di bidang fikih sosial yang lahir di Wani Donggala. Pada usia 2 tahun, ia pindah Ke Parepare Bersama Ayahnya KH. Muhamammad Al Yafie. Ali Yafie belajar secara non formal ke bapaknya yang dikenal sebagai ulama. Di samping itu, ia bersekolah di Vervolg School sebuah sekolah Belanda (Parepare). Selanjutnya, ia ikut bapaknya yang pindah ke Rappang belajar pada Syekh Ali Mathar di Madrasah Aunur Rafiq dan KH. Ibrahim (Qadi Sidenreng). Pada usia sekitar 17 tahun ia menikah dengan Aisyah Umar (saudara KH. Muhsin Umar) di Jampue Pinrang. Selanjutnya pengembaraan ilmiahnya dilanjutkan di Bone pada Syekh Mahmud al Jawwad. Sepulang dari Bone, ia pun sempat belajar kepada Syekh Abdurrahman Firdaus di Jampue.

Pada tahun 1948, pasca muktamar pertama DDI, Ali Yafie diserahi amanah sebagai Sekretaris DDI. Ia merupakan anggota DDI paling muda dengan usia 19 tahun. Ali Yafie muda tidak canggung mengemban amanat sebagai pengurus DDI berdampingan dengan ulama-ulama lainnya yang usianya lebih senior. Dengan kedalaman ilmunya walaupun masih dalam usia yang cukup muda, pada 1953 ia diutus oleh DDI menghadiri Kongres Ulama Indonesia di Medan bersama KH. Abd. Rahman Bone, KH. Amberi Said dan KH. Muhammad Abduh Pabbajah. Hingga pada pada periode 1962-165 saat Gurutta Ambo Dalle masih di hutan bersama Gerombolan DI/TII, ia diserahi amanah sebagai Ketua Umum PB DDI. Pada saat itu pula kedudukan PB DDI berpindah ke Makassar. Kecemerlangan karirnya di bidang intelektual, organisasi, dan politik mengantarkan Ali Yafie berkarir di Jakarta. Hingga akhirnya, ia pernah menjabat sebagai Rais Syuriah Nahdatul Ulama (1991-1992) dan Ketua Majelis Ulama Indonesia (MUI) Pusat (1998-2000).

\section{Pembentukan Jaringan Ulama}

Sejak dahulu Mekah menjadi tujuan para ulama belajar agama tak terkecuali ulama di Sulewesi Selatan sepeti dari daerah Pinrang. Diantaranya yang terkenal yaitu pendiri MAI Sengkang KH. Muh. Asad. Ia berguru kepada banyak ulama di Mekah diantara gurunya yakni Sykeh Said alYamani, Ia merupakan ulama keturunan Bugis kelahiran Mekah, ayahnya adalah Syekh Abdul Rasyid ulama Bugis yang sudah lama bermukim di Mekah. Disamping 
belajar pada Syekh Said Al Yamani, ia juga belajar pada Syekh Umar Hamdani al-Magribi, Syekh Jamal al Makki, Syekh Ahamd Nazirin, Syekh Hasan al Yamani (putra Syekh Said al Yamani) dan lain sebagainya (Katu, 2007, p. 231). Gurutta Muh. As'ad kemudian pulang ke Sengkang dan mendirikan MAI Sengkang Wajo. Banyak dari murid-muridnya yang kemudian melanjutkan perjuangannya menyebarkan pendidikan agama di Sulawesi termasuk Pinrang seperti, Abdurrahman Ambo Dalle yang mendirikan Pesantren DDI Manahil Ulum Kaballangan Pinrang atau KH. Zainal Abidin yang mendirikan pengajian tradisional di Pinrang.

Selain Muh. As'ad, ulama Sulawesi lainnya yang langsung belajar ke Mekah yaitu Habib Hasan bin Alwi Jamalul Lail seorang ulama keturanan Arab yang menetap Ujung Lero Pinrang kelahiran Pambusuang Mandar. Ayahnya seorang Ulama besar bernama Habib Alwi bin Abdullah Bin Sahl Jamalullail yang dikenal sebagai guru dari Muhammad Thahir (imam Lapeo). Habib Hasan sejak dini dikirim oleh ayahnya ke tanah Suci Mekah kepada berguru ke beberapa ulama kurang lebih 30 tahun lamanya. Hanya saja dari sekian gurnya, hanya nama Syekh Said al Yamani Mufti Syafi'iyyah yang diketahui. Setelah itu, ia kemudian pulang ke Mandar tepat ke tanah kelahirannya Pambusuang menyebarkan dakwah Islam sekaligus mengadakan pengajian kitab kuning dan merintis pembangunan Masjid alTaqwa Pambusuang. Di tempat inilah kemudian menjadi pusat lahirnya ulama-ulama Pambusuang yang mengembangkan pengajian tradisonal kitab kuning hingga kini. Seperti disebutkan di atas, bahwa setelah para ulama tersebut pulang dari Mekah, mereka kemudian membentuk jaringan intelektual dalam skala lokal dalam bentuk pengajian atau lembaga pendidikan

Disamping dengan model jaringan tersebut di atas, beberapa ulama juga menuntut ilmu dalam skala lokal di Sulawesi yakni mereka menemui ulama di daerah Sulawesi seperti Salemo, Campalagian atau Senkang yang pada awal Abad-20 menjadi pusat pengembangan Pendidikan Islam di Sulawesi Selatan. setelah itu, mereka kemudian mentransformasikan ilmu agama ke masyarakat. Di beberapa tempat di Pinrang, banyak ulama yang memilih melaksanakan proses pembelajaran agama. Kader ulama Salemo yang cukup terkenal di Pinrang adalah KH. Abd. Shamad. Ia merupakan ulama sepuh sebelum Ambo Dalle hijrah ke Kaballangan. Di Pinrang ia memilih model pendidikan tradisional kitab kuning yang dipusatkan di rumahnya dan Masjid Raya Pinrang. Pengajian di rumah dikhususkan bagi santri yang belajar secara khusus kitab kuning dengan terlebih dahulu materi Nahwu Sharaf. Beberapa ulama yang pernah belajar padanya diantaranya yaitu: $\mathrm{KH}$. Zainal Abidin, KH. Abd. Hafid Karim, KH Said Mantakka, dan lain sebgainya. Di Masjid Raya Pinrang, ia mengajarkan kitab Kasyifah al Saja dan Kifayah al-Akhyar kitab fikih bermazhab Syafi'iyyah. Pengajian ini dikhususkan pada masyarakat yang ingin memahami fikih Islam dan dilaksanakan setelah salat berjama'ah. Selain Abd. Shamad, beberapa ulama 
dari Langnga juga memilih metode yang sama dalam mengembangkan pendidikan agama seperti KH. Abd. Latif (alumni Campalagian) dan $\mathrm{KH}$. Rabe Baddulu.

Di wilayah pesisir pantai, peran Habib Hasan bin Alwi juga tak bisa dinafikana. Ia adalah ulama keturunan Ahlul Bait kelahiran Pambusuang Mandar yang memutuskan hijrah ke Ujung Lero akibat gerakan DI/TII. Di ujung ia mendirikan Masjid al Muhajirin sekalgus mengembankan pengajian kitab kuning secara tradisional. Muridnya yang terkenal yaitu KH. Muchtar Husain mantan Ketua MUI Sulawesi Selatan. Konon berdasarkan tradisi lisan, bahwa Gurutta Ambo Dalle ketika menetap di Pare-pare sering menyambangi Habib Hasan untuk berdiskusi dan bertukar pikiran.

Di Jampue Pinrang, sistem tradisional ini juga ditempuh oleh Muhsen Umar dan Ali Yafie. Muhsen umar belajar pada Syekh Khaidar Musa. Disamping itu juga belajar langsung pada Syekh Abdurrahman Firdaus yang menetap di Jampue. Atas rekomendasi Syekh Abdurrahman Firdaus, ia juga belajar kepada Syekh Ali Kudus (ulama asal, lahir di Makkah, yang meninggal Makkah bersama Syekh Abdurrahman Firdaus, yang kemudian menetap di daerah Bugis). Informasi tentang Syekh Ali Kudus diperoleh melalui cerita lisan. Konon, Syekh Ali Kudus menetap di daerah pesisir Pinrang tepatnya yaitu daerah Langnga. Ia adalah Putra Syekh Abdul Hamid Kudus, yang lahir dan mukim di Mekah sampai akhir hayatnya. Syekh Abdul Hamid Kudus, adalah ulama (guru besar) di Mekah dan mempunyai banyak murid yang merupakan sahabat KH. Muh. As'ad di Sengkang (Wawancara dengan Helmi Ali).

Seperti halnya Muhsen Umar, Ali Yafie juga belajar pada Syekh Abdurrahman Firdaus di Jampue. Cara bergurunya unik. Syekh Abdurrahman Firdaus memberinya kitab, setelah dibaca Syekh Abdurrahman Firdaus mengajaknya mendiskusikan kitab itu. Jadi kitab yang menjadi materi dibaca dulu oleh Ali Yafie, setelah itu dia datang ke Syekh Abdurrahman Firdaus berdiskusi dan berdebat. Begitulah cara Syekh Abdurrahman Firdaus mengajari Ali Yafie hingga memiliki nalar kritis yang kuat (Wawancara dengan Helmi Ali Yafi).

Selain dengan metode pengajian dengan sistem tradisional, pendirian lembaga pendidikan agama di Pintang juga menjadi model pembentukan jaringan ulama. Adalah KH. Abd. Rahman Ambo Dalle yang mendirikan Pesantren Manahil al-Ulum. Sebelumnya, usaha seperti ini lakukan dengan mendirikan pesantren DDI Mangkso di Barru serta DDI di Ujung Lare.di Parepare. Lembaga pendidikan ini masih eksis hingga kini, diasuh oleh ulama penerus yang hampir semuanya merupakan murid langsung $\mathrm{KH}$. Abdurahman Ambo Dalle.

\section{PENUTUP}

Problem utama dalam melacak jaringan ulama Sulawesi Selatan yaitu masih banyak ulama yang belum tertulis dalam kajian ilmiah sehingga 
data dan informasi seputar ulama tertentu sangat terbatas. Secara garis besarnya, jaringan pengabdian ulama di daerah Pinrang dibagi ke dalam beberapa model, yaitu: Pertama, Ulama tradisional mengadakan pengajian kitab kuning. Model jaringan ini diwakili oleh Habib Alwi (Ujung Lero, Pinrang) dan KH. Abd. Shamad (Langnga, Pinrang) Kedua, Ulama menyebarkan ajaran tarekat seperti yang dilakukan oleh KH. Muhsin Umar (Tarekat Syadziliyah Jampue Pinrang). Ketiga, ulama yang mendirikan organisasi dan lembaga pendidikan keagamaan seeprti yang dilakukan $\mathrm{KH}$. Abdurrahman Ambo Dalle dengan mendirikan Pesantren Darud Dakwah Wal Irsyad (DDI) Manahil Ulum Kaballangan Pinrang.

Sementara jaringan keilmuan ulama berupa tempat asal belajar secara garis besar dibagi menjadi; Pertama, Jaringan Haramayn yaitu ulama yang mengenyam pendidikan di tanah suci Mekah seperti Habib Hasan yang berguru pada Said al Yamani dan ulama lainnya. Disamping itu juga, ada beberapa ulama yang awalnya belajar di beberapa daerah di Sulawesi lalu kemudian memperdalam ilmu agama di tanah Mekah, seperti, KH. Abdurrahman Ambo Dalle dan KH. Abd. Shamad,. Kedua, jaringan lokal yaitu ulama yang hanya belajar di tanah beberapa daerah di Sulawesi Selatan seperti; KH. Muhsin Umar dan KH. Ali Yafie.

Pembentukan jaringan keilmuan ulama pada umumnya diawali dari sistem tradisional maupun madrasah yang mengedapankan pada penguasaan kitab yang berbahasa Arab. Pada tahap selanjutnya para ulama membentuk lembaga pendidikan berupa madrasah dan pesantren sebagai upaya melanjutkan tradisi keulamaan kepada generasi berikutnya. Hanya saja, tradisi kajian kitab yang berbasis penguasaan bahasa Arab pada generasi terakhir mengalami kemunduran. Hal ini terjadi karena adanya perubahan kurikulum dengan menyesuiakan kurikulum yang diberlakukan pemerintah sehingga opsi kajian kitab semakin berkurang. Di samping itu, kurangnya kader ulama maupun ustadz yang bisa mengajarkan kitab berbahasa Arab turut menjadi menyebab kemunduran lembagalembaga pesantren dan madrasah. Di sisi lain, opsi pengajian non formal dalam bentuk pengajian traidisional kitab kuning yang diselenggarakan oleh ulama semakin langka di temui di berbagai wilayah di Sulawesi Selatan.

\section{UCAPAN TERIMA KASIH}

Artikel ini adalah bagian dari hasil penelitian yang dilakukan di lingkungan Litbang Agama Makassar. Karena itu, saya mengucapkan terimakasih kepada Kepala BLAM yang telah mempercayakan tugas ini kepada saya. Terimakasih kepada para informan yang telah memberikan bantuan dalam terlakasananya penelitian ini. Demikian juga terimakasih tak terhingga kepada saudara Husnul Fahima Ilyas dan Muh. Subair yang telah memberikan bimbingan dalam proses penelitian sampai pada penulisan artikel. 


\section{DAFTAR PUSTAKA}

Anshory Ch, H. M. N. (2009). Anregurutta Ambo Dalle: Maha Guru Dari Bumi Bugis. Yogyakarta: Tiara Wacana Yogya.

Arif, S. (2008). Jaringan Pesantren di Sulawesi Selatan (1928-2005). Jakarta: Badan Litbang dan Diklat Kementerian Agama RI.

Azra, A. (2007). Jaringan Ulama Timur Tengah dan Kepulauan Nusantara Abad XVI \& XVII. Jakarta: Kencana.

Dhofier, Z. (2011). Tradisi Pesantren: Studi Pandangan Hidup Kyai dan Visinya Mengenai Masa Depan Indonesia. Jakarta: LP3ES.

Gottschalk, L. (2006). Undersatnding History: A Promer Of Hsitorical Method, Diterjemahkan oleh Nugroho Notosusanto dengan Judul: Mengerti Sejarah. Jakarta: UI Press.

Hamid, W. (2018). Jaringan Ulama Awal Abad XX Kabupaten Sidrap dan Parepare. PUSAKA. https://doi.org/10.31969/pusaka.v $6 \mathrm{i} 2.53$

Hamid, W. (2019). Jejak dan Kiprah Ulama Pinrang Awal Abad XX. Jurnal Al-Qalam, 25.

Kabry, A. M. (2006). Darud Da'wah Wal Irsyad Dalam Simpul Sejarah Kebangkitan dan Perkembangan.

Katu, M. A. (2007). AGH. Muhammad As'ad: Gurunya Ulama Sulawesi Selatan. In Ulama Sulawesi Selatan: Biografi Pendididkan dan Dakwah. Makassar: Komisi Informasi dan Komunikasi Majelis Ulama Indonesia Provinsi Sulawesi Selatan.

Kila, S. (1998). Sejarah Islam di Daerah Pinrang. Ujung Pandang: Balai Kajian dan Nilai Tradisional.

Lubis, N. (1996). Syekh Yusuf Al-
Makassari: Menyingkap Intisari Segala Rahasia. Bandung: Mizan.

Ondeng, S. (2007). AGH. Abdurrahman Ambo Dalle: Pendiri Darud Dakwah Wal Irsyad. In Ulama Sulawesi Selatan: Biografi Pendididkan dan Dakwah. Makassar: Komisi Informasi dan Komunikasi Majelis Ulama Indonesia Provinsi Sulawesi Selatan.

Pawiloy. et.al, S. (1981). Sejarah Pendidikan Daerah Sulawesi Selatan. Ujung Pandang: Departemen Pendidikan dan Kebudayaan Proyek Inventarisasi dan Dokumentasi Kebudayaan Daerah.

Ridhwan. (2016). Pendidikan Islam Masa Kerajaan Bone; Sejarah, Akar dan Corak Keilmuan serta Peranan Kadi. Kampus Bukit Indah Lhokseumawe: Unimal Press.

Ritzer, G. (2014). Eigth Edition Siciology Theory. Diterjemahkan oleh Saut Pasaribu et. al. dengan Judul Edisi Kedelapan Teori Sosiologi: Dari Sosiologi Klasik Sampai Perkembangan Terakhir Postmodern. Yogyakarta: Pustaka Pelajar.

Sahl, H. T. bin. (2014). Mutiara Tarim Sampai Ke Tanah Mandar: Dari Manaqib al-Allamah al-Habib Alwi Bin Abdullah bin Sahl Jamalullail.

Sewang, A. M. (2005). Islamisasi Kerajaan Gowa (Abad XVI Sampai Abad XVII). Jakarta: Yayasan Obor Indonesia.

Subair, Muh. (2011). K.H. Muhammad Abduh Pabbajah; Sang Penceah di Kalangan Anak Muda. In Buah Pena Sang Ulama (pp. 131-156). Makassar: Orbit. 
Subair, Muhammad. (2018). AGH Huzaifah dalam Pusaran Tradisi Santri di Qismul Huffadz Pesantren Biru Bone. Jurnal Pusaka, volume $6 \mathrm{~N}$.

Sudirman. (2008). Efektifitas Metode Halaqah Dalam Peningkatan Akhlaq Al-Karimah Santri Pada Pondok Pesantren Ihya'ul Ulum DDI Baruga Kab. Majene. Sekolah tinggi Agama Islam DDI Majene.

Sugiyono. (2010). Metode Penelitian Pendidikan (pendekatan Kualitatif, Kuantitatif, dan R\&D). Bandung: Afabeta. 
Indeks Judul

Vol. 8, No. 2, November 2020

Islamisasi di Ajatappareng Abad XVI-XVII, 191

Jaringan Intelektual Ulama Pinrang, 227

Kearifan Lokal Sintuwu Maroso sebagai Simbol Moderasi Beragama, 241

Korelasi Fungsional Kalender Islam dan Pembayaran Zakat, 179

Makna dan Simbol Pada Tradisi Pembacaan Ratek Mauduk di Komunitas Makassar, 165

Mengilhami Kreativitas Keberagamaan Masyarakat Melalui Perjumpaan Islam dan Patuntung di Tanah Toa Kajang, 145

Merajut Moderasi Beragama dari Tradisi Pesantren, 211

Tradisi Siklus Hidup Masyarakat Perkotaan di Era Normal Baru (Studi Living Qur'an Pada Masyarakat Pedalangan, Banyumanik, Semarang), 125 
Indeks Penulis

Vol. 8, No. 2, November 2020

Abd. Kadir M, 211

Ahmad Yani, 191

Husnul Fahimah Ilyas, 165

Mita Melina, Ulfi Putra Sany, dan Mustolehudin, 125

Muh. Rasywan Syarif dan Naif, 179

Muhammad Nur, 241

Syarifuddin, 227

Sylviah dan Abu Muslim, 145 


\section{Ketentuan Pengiriman Tulisan \\ Pusaka Jurnal Khazanah Kegamaan}

Pusaka Jurnal Khazanah Keagamaan adalah terbitan yang bersifat ilmiah, berisi tulisan hasil penelitian dan kajian dalam bidang Khazanah Keagamaan. Artikel yang dikirim ke redaksi diharapkan mengikuti ketentuan sebagai berikut:

> Naskah harus berupa hasil penelitian atau kajian pustaka yang belum dan tidak dalam proses publikasi pada media cetak lain, dikirim dalam bentuk file word doc ke OJS web: https://blamakassar.ejournal.id/pusaka/index jika mengalami kesulitan dapat menghubungi admin melalui email: pusakajurnal@gmail.com

$>$ Naskah diketik dengan spasi 1 di atas kertas ukuran A4, dengan huruf Times New Roman 12. Batas semua sisi kiri dan bawah $4 \mathrm{~cm}$, atas dan kanan $3 \mathrm{~cm}$. Jumlah kata minimla 5000 dan maksimal 10000 atau sekitar 15-20 halaman, menggunakan bahasa Indonesia, bahasa Inggris, atau bahasa Arab, disusun dengan urutan sebagai berikut:

Penulisan artikel hendaknya memenuhi unsur-unsur berikut:

Judul: tidak lebih dari 15 kata

Nama

Intansi

Alamat

Email

Abstract: minimial 180, maksimal 200 kata, terdiri dari 2 kalimat dari setiap bagian artikel

Keywords: (5 keywords) $=3$ kata berasal dari judul

Introduction (4 paragraf)

Paragraph 1 (Fakta)

$>$ Shocking statement

$>$ Penjelasan sedikit tentang tema yang akan diangkat

$>$ Data

$>$ Pernyataan ahli tentang topik yang akan dibahas

\section{Paragrpah 2 (Fakta literature)}

$>$ Aspek yang sudah diteliti (3 - 4 literature)

$>$ Kutipan (1-2) literature yang menjelaskan fakta

$>$ Ditutup dengan gap (aspek yang belum diteliti yang berhubungan dengan topik tersebut)

Paragraph 3: Tujuan penelitian. Misalnya tulisan ini bertujuan untuk: Melengkapi, menjelaskan, memetakan

Paragraph 4: Argumen/hipotesis/ asumsi/ kesimpulan awal 1, 2 dst...

Literature Review (agar tidak DUPLIKASI/plagiat, dan untuk meminjam konsep-konsep yang telah dipakai peneliti terdahulu) (9-10 paragraf)

$>$ Profil penelitian sebelumnya, kecenderung dan tipologi (aspek/isu yang dikaji cenderung? Pendekatan yang digunakan cenderung? Hasil yang diperoleh apa??) (1-2 paragraf)

$>$ Definisikan konsep2 penting (6 paragraf)

Method (3-5 paragraf)

Pilihan objek (tempat, kasus, isu)

Jenis penelitian: kualitatif/survey $=>$ data yang diperlukan

$>$ Sumber informasi: informan atau responden

$>$ Teknik pengumpulan data: observasi, wawancara (siapa? Berapa orang?), content analysis (mapping)

$>$ Analisis: proses analisis (tahapan analisis) dan teknik analisis (interpretasi) 
Results: BUKTI BUKTI / Penyajian Dan Pengkategorian DATA ( Jawaban WHAT??)

Discussion: PEMBAHASAN=MENGAPA (Menjawab SO-WHAT? WHY??)

Conclusion (3 paragraf)

$>$ Temuan terpenting? Apa yang baru kita tahu setelah ada penelitian? (Ternyata!)

$>$ Apakah teori/konsep/metode yang digunakan dapat menjawab pertanyaan penelitian?

$>$ Keterbatasan penelitian? Saran penelitian lanjutan....

Ucapan terimakasih, kepada mereka yang banyak memberikan bantuan dalam tulisan tersebut.

Daftar Pustaka, minimal 16 judul, dan 80\% acuan yang digunakan dari terbitan 10 tahun terakhir dan hendaknya $80 \%$ acuan berupa sumber primer. Daftar pustaka hanya sumber yang terdaftar dalam tulisan, bukan daftar bacaan, ditulis dan disusun secara abjad dengan mengacu pada american psychological association (apa) style 6th edition, diharuskan menggunakan aplikasi MENDELEY atau sejenisnya.

Semua jenis rujukan harus diintegrasikan dengan sistem aplikasi mendeley atau sejenisnya, apabila merujuk dari sumber internet, hendaknya mengambil sumber yang bertanggung jawab dengan mengetahui nama, organisasi, atau pihak yang bertanggung jawab atas pernyataan yang dikutip.

\section{Ketentuan tambahan:}

Tabel, gambar, dan grafik diberi nomor urut; ilustrasi tersebut harus jelas terbaca. Judul tabel ditulis di sebelah atas tabel yang bersangkutan, sedangkan judul gambar dan gambar di sebelah bawah ilustrasi masing-masing.

Tulisan yang menggunakan transliterasi Arab-Latin, penulis hendaknya berpedoman pada Pedoman Transliterassi Arab-Latin SKB Dua Menteri, Menteri Agama RI Nomor 158 Tahun 1987 dan Menteri Pendidikan dan Kebudayaan RI Nomor 0543 b/u/1987 tentang Pedoman Transliterasi Arab Latin.

\section{Seleksi Tulisan}

- Proses seleksi naskah meliputi: seleksi awal, penyuntingan oleh Dewan Redaksi, Review (penelaahan) oleh Mitra Bestari, dan persetujuan naskah.

- Kriteria penilaian mencakup kesesuaian dengan persyaratan, sistematika, derajat originalitas alur penulisan, kedalaman ilmiah, unsur kebaruan (novelty), nilai manfaat hasil penelitian.

- Menanda tangani surat keterangan klirens etik atau tidak plagiasi

- Redaksi berhak menolak, mengembalikan untuk diperbaiki atau mengedit kembali naskah tanpa merubah isi dan maskud tulisan.

\section{Lain-lain}

- Redaksi tidak bertanggung jawab setiap pernyataan dan pendapat yang dikemukakan penulis

- Artikel dalam bentuk file word doc dikirim melalui OJS, di laman web: https://blamakassar.ejournal.id/pusaka/index jika mengalami kesulitan dapat menghubungi admin melalui email: pusakajurnal@gmail.com 